\title{
Community-wide stable isotope analysis reveals two distinct trophic groups in a service-providing carabid community - ERRATUM
}

\section{S. Kamenova, C. Leroux, S.E. Polin and M. Plantegenest}

doi:10.1017/S0007485317000542, Published by Cambridge University Press, 15 June 2017.

The publisher apologises for an error during the typesetting process where a correction was inserted incorrectly. The Acknowledgements section should read as follows:

\section{Acknowledgements}

This study was a part of a wider project and the authors greatly thank all persons that voluntereed for the fieldwork: Frédéric Hamelin, Nolwenn Génuit, Maël Dugué, Kévin Tougeron, Théo Vantsteenkeste, Frédérique Mahéo, Lucie Mieuzet, Nathalie Leterme, Jean-François Le Gallic, Bernard Chaubet and Sarah Polin. The authors also thank the LTER Area 'Armorique' for providing infrastructures as well as the network of farmers that kindly allowed them to sample in their fields. Finally, the authors thank the two anonymous referees for their insightful suggestions on the first version of the manuscript. This study was funded by the French National Research Agency through the 'Landscaphid' project ANR-09-STRA-05 and the 'Peerless' project ANR-12-AGRO-0006.

\section{Reference}

Kamenova, S., Leroux, C., Polin, S.E. \& Plantegenest, M. Community-wide stable isotope analysis reveals two distinct trophic groups in a service-providing carabid community. Bulletin of Entomological Research. Published by Cambridge University Press, 15 June 2017. doi:10.1017/S0007485317000542. 